\title{
INTEGRATION OF ENVIRONMENTAL EDUCATION (EE) IN TEACHER EDUCATION PROGRAMS: TOWARD SUSTAINABLE CURRICULUM GREENING
}

PROBLEMS

OF EDUCATION

IN THE $21^{\text {st }}$ CENTURY

Vol. 80 , No. 1,2022

119

\author{
Alma M. Corpuz \\ Tarlac State University, Philippines \\ E-mail: almamarcelinocorpuz@gmail.com \\ Teody C. San Andres \\ Bulacan State University, Philippines \\ E-mail: teodysanandres.evp@bulsu.edu.ph \\ Julieta M. Lagasca \\ Tarlac State University, Philippines \\ E-mail: jd_102885@yahoo.com
}

\begin{abstract}
Environmental education (EE) is vital in addressing global environmental problems. Educational institutions are integrating EE into their curricula, but studies indicated the need for its intensification. This mixed method study assessed the integration of EE in Teacher Education Programs (TEPs) in Region III, Philippines. Respondents were 10 program deans, 10 chairs, 171 teachers, and 344 students. Data were gathered using validated questionnaires. Findings revealed that the New Teacher Education Curriculum (NTEC) integrated EE in program outcomes and performance indicators; in mandated courses -Physical Education (PE) and National Service Training Program (NSTP); and in Science Technology and Society (STS), a General Education (GE) course. Likewise, teachers integrated EE in their lessons and in community extension programs. Seminars/webinars included environmental care and promoted environmental awareness in social media. As to support for EE integration, administrative, physical facilities and financial support were provided. On student outcomes, positive findings were shown on attitude towards environment care, but application of knowledge and skills needs improvement. Students' knowledge was significantly correlated to attitude (Pearson's $r$ value is.593 and p value <.05) as well as skills acquisition and attitude (Pearson's $r$ value is .647 and $p$ value <.05). Teachers' challenges in the EE integration included inadequate environmental knowledge and lack of time to lead students in environmental action. The study concludes that EE is integrated into the TEPs but the outcomes on the learners' knowledge and skills acquisition still need strengthening. Also, EE should be integrated in professional education courses, not only in GE and mandated courses.

Keywords: assessment, integration of environmental education, mixed method, sustainable curriculum greening, teacher education programs
\end{abstract}

\section{Introduction}

Climate change (CC) continues to threaten the world (United Nations, 2020) and the environmental effects are occurring earlier than predictions. These include shrinking glaciers, accelerated rising of sea level, more intensified heatwaves, and shifting of plants and animals (Global Climate Change, 2021). The environmental changes affected the globe. Even USA, the most powerful country, is bombarded with environmental problems which include 
Alma M. CORPUZ, Teody C. SAN ANDRES, Julieta M. LAGASCA. Integration of environmental education (EE) in teacher education programs: Toward sustainable curriculum greening

PROBLEMS

OF EDUCATION IN THE $21^{\text {st }}$ CENTURY Vol. 80 , No. 1,2022

120

deforestation; air pollution; global warming due to melting ice glaciers; intense hurricanes and water pollution due to sewerage getting into water pipes; and chemical contamination of water bodies from pesticides, and natural resource depletion (Tsui, 2020). Likewise, in Southeast Asia, six environmental issues include endangered species conservation, air pollution, destruction of coral reefs, deforestation, water security, and increased urbanization (Hershberger, 2014).

Taking environmental issues into the equation, the United Nations had developed 17 Sustainable Development Goals (SDGs). Goals that directly affect environmental issues are SDG6 (clean water); SDG7 (clean energy); SDG 12 (responsible consumption); SDG 13 (Climate Action); SDG 14 (life underwater); and SDG 15 (life on land). UN targets the realization of these goals by 2030 (SDG, 2020). To realize the SDGs targeting environment development, government leaders across countries in the world need to find more effective mitigating measures. However, while government leaders are to be the CC czars, the Commonwealth of Education Hub (2020) asserts a multisectoral approach to respond to this global issue. This is supported by the DENR secretary of the Philippines who stated that "the realization of the SDGs relative to environmental issues and problems, is not the sole responsibility of the government but of all individuals."

One of the sectors seen as potential platforms of environmental action (EA), is education. Schools are strategic avenues in the development of students' attitude and help them become CC active advocates through increased climate literacy and CC-related trends (United Nations Educational, Scientific, and Cultural Organization, n.d.). Environmental education in curricular programs enables youth engagement in green growth (Climate Change Commission, 2011); development of informed decision-making skills; active environmental involvement as influencers; and in adaptation of sustainable lifestyles (UNESCO, n.d.). Teaching CC and helping students understand it, is no longer just an interest of scientists. So, teachers must integrate elements of $\mathrm{CC}$ into their instructional plans to enable student knowledge on how they can participate in addressing CC problems to their capacity level. Students must understand that $\mathrm{CC}$ has consequences for the earth and human lives, and they have vital role to play to address the negative effects.

The features of EE include EA and mindfulness; environmental knowledge and learning; positive attitudes; skills; participation; and promotion of green facilities (Conserve Energy Future, n.d.). These features hope to allow individuals to explore environmental issues, engage in problem solving, and take action to improve the environment. Moreover, EE would result in individuals having deeper understanding of environmental issues; possessing skills to make informed decisions; and becoming responsible for their actions (EPA, 2018). Integration of EE in educational curricula will potentially lead to the youths' acquisition of knowledge, skills and attitude that will make them vital agents of environmental protection.

Countries abroad like India (Verma \& Dhull, 2017), Tanzania, (Mwendwa, 2017), and Botswana (Velimpini, 2016) have integrated EE into various sectoral and educational curricula. In the Philippines, EE is also integrated in various institutions, especially in education. However, literature and studies reviewed showed the need to strengthen EE programs (Department of Education, 2020), conduct assessment of integration outcomes, identify issues in the integration (Marpa, 2020), and determine if integration attempts are effective and sustainable (Perez \& Bua, Jr., 2019).

Additionally, Labog (2018) determined the correlation between teachers' integration of EA and level of sustainable development practices of selected public high schools in a district of Oriental Mindoro. The study findings revealed that teachers integrate EA topics on waste management, forest conservation and climate change in their class lessons. Teachers had enabled student acquisition of knowledge and understanding of global environmental issues and students, but more involvement is needed to become responsible environmental and sustainable citizens. Garcesa and Limjuco (2016) also determined the relationship between the level of 
environmental literacy and level of integration of environmental issues of Science teachers in Region XI. The study found that Science teachers had high level of overall environmental literacy and integration of environmental issues. A significant correlation was found between environmental literacy and level of integration of environmental issues. This indicates widespread environmental literacy in the school for better outcomes on environment action.

The studies of Labog (2018) and Garccesa and Limjuco (2016) affirmed the integration of environmental issues in high school education curriculum but both studies did not explore the outcomes of such integration on the learners. The present study investigated the outcomes of the IEE in the NTEC in terms of knowledge and skills acquisition and development of positive attitude towards environmental action. Similarly, Abun and Racoma (2017) also analyzed the environmental attitude of employees of a school in Ilocos. The findings revealed that the employees generally had ambivalent environmental attitudes which were affected by lack of understanding about environmental ethics. The study then recommended the need to improve the awareness or understanding about natural environment through seminars on environment and environmental ethics in the curriculum.

Moreover, the Commission on Higher Education (CHED) and Department of Education (DepED have crafted policies, guidelines, programs, projects, and activities which support the integration of climate change adaptation and mitigation and environmental education through CHED Memorandum (CMO)No. 33, series of 2009, CMO No. 52, s of 2016, and DepED Order No. 33 s. 2011. The initiatives are seen in research priority programs, curricular enhancements, and extension activities. CHED (2012) cited the research of Eileen Bernardo of Isabela State University on curriculum enhancement and biodiversity emphasizing that HE plays a critical role in preparing/providing the leadership to meet challenges in these areas; HEIs are well placed to contribute to the process; and HEIs can make meaningful contribution in providing solutions to the challenges posed by CC and biodiversity loss. However, the study concluded that educational initiatives related to $\mathrm{CC}$ lacked coordination and cooperation among HEIs. Accordingly, there are still many structural obstacles for a real integration in curricula and daily classroom work.

Further measures to promote climate change and EA pursuant to Republic Act (R.A.) No. 9512, "An Act to Promote Environmental Education and for Other Purposes" were DO No. 52, series of 2011, "Strengthening Environmental Education in Public and Private Schools;" DO No. 93, series of 2011, "Mandates Programs, Projects and Activities under the Youth for Environment in Schools Program;" and Department Memorandum No. 019, series of 2018 or the "Activities of the DENR," (DepEd, 2011, 2018; Environmental Management Bureau, n.d.). The DepED also included "makakalikasan" (pro-environment) in the core values statement (DepED, n.d.).

However, Perez and Bua, Jr. (2019) concluded in their study that the concept of sustainable development is not yet in the current $\mathrm{K}$ to 12 curriculum and all standards based on DepED Order No. 08, series of 2015 were only "moderately" achieved by secondary schools. The researchers concluded that sustainability of environmental projects is unclear and the inadequate resources to support integration programs served as hindrances. Other problems identified were mobility of various resources managed by the residents and continuation of projects due to shifting interest of community leaders and sources of funds. The researchers recommended the inclusion of EE in co-curricular projects as researchers took notice of the growing interest in $\mathrm{EE}$ among the members of the community and the possible cooperation of agencies as potential opportunities for improved IEE secondary school level.

Hence, the researchers deemed it necessary to assess the integration of EE in school curricula. Findings are necessary to strengthen the role of education in addressing environmental issues and problems. Curriculum developers, which include school heads, teachers and stakeholders must have thorough grasp of their role in the integration of EE into educational 
Alma M. CORPUZ, Teody C. SAN ANDRES, Julieta M. LAGASCA. Integration of environmental education (EE) in teacher education programs: Toward sustainable curriculum greening

PROBLEMS

OF EDUCATION IN THE $21^{\text {st }}$ CENTURY Vol. 80 , No. 1, 2022

122

curricula so they can effectively bridge the gap that hinders youth environmental empowerment. Strategic integration of EE in daily classroom activities would effectively fulfill the role of education in environment awareness and action.

The present study determined and analyzed the integration of EE in the New Teacher Education Curriculum (NTEC) in Region III State Universities and Colleges (SUCs). The researchers believe that equipping teachers as environmental advocates should start in their training stage. So, EE should be effectively ingrained in the curriculum.

\section{Research Problem}

Clearly, the role of education is vital in raising the environmental awareness of students and in motivating them to take part in programs launched to mitigate environmental problems. However, while the efforts to integrate EE into various curricular programs are apparent, cited literature and studies suggest the need to further strengthen programs to attain success. For example, DepEd recently launched the "Search for Sustainable Eco-Friendly Schools," in partnership with the DENR, Environmental Management Bureau (EMB) and the CHED (Malipot, 2019). This program hopes to address the need to increase climate change awareness and environmental consciousness of students. In addition, support to teachers' integration of climate change in the curriculum was heightened through the availability of curated resources for teaching climate change for School Year 2020-2021 (DepED, 2021). The learning materials will lessen the burden of teachers to develop environmental awareness learning resources for their students.

This study then aimed to assess the integration of EE in TEPs in the SUCs of Region III, Philippines in terms of the strategies, outcomes and challenges encountered. Findings led to the development of enhancement measures that TEPs may implement to equip and empower students to take care of the environment.

\section{Research Focus}

The present study analyzed how the SUCs in Region III, Philippines integrated environmental education into the NTEC. The contents of the latest CMOs governing the offering of BEEd and BSEd programs were analyzed in terms of specific provisions related to environmental education; policies, guidelines, and programs for the integration of EE; and classroom teaching-learning activities that integrate EE. Moreover, outcomes of the EE integration on students' knowledge, skills, and attitude were determined. Currently, integration of EE in the New Teacher Education Curriculum and have not been explored in as well as the outcomes of the IEE on the students' knowledge, skills, and attitude. The findings of the study were inputs to the development of proposed measures to deepen the integration of EE into the BSEd and BEEd programs for sustainable curricular greening.

\section{Research Aim and Research Questions}

The study aimed to assess the integration of EE in the NTEC among SUCs in Region III, Philippines. The following questions were answered:

1. How is EE integrated in the NTEC?

2. What are the outcomes of integration of EE among the students in terms of environmental knowledge, skills, and attitude?

3. Is there a significant correlation between knowledge and skills outcomes and attitude of the students? 
Alma M. CORPUZ, Teody C. SAN ANDRES, Julieta M. LAGASCA. Integration of environmental education (EE) in teacher education programs: Toward sustainable curriculum greening

4. What is the school management support provided in the integration of EE in the NTEC?

5. What are the challenges in the integration of EE in NTEC?

6. What enhancements could be proposed in NTEC for IEE for sustainable curriculum greening?

\section{Hypothesis}

There is no significant correlation between knowledge and skills outcomes and attitude of the students.

\section{Research Methodology}

\section{General Background}

The study assessed the strategies of the TEPs in the integration of EE (curriculum greening) into NTECs among SUCs in Region III, Philippines. A mixed quantitative and qualitative design was employed in data gathering and analysis. Quantitative data were gathered using closed-ended questionnaires. Qualitative data were gathered through openended questionnaires and documents relative to curricular contents and provisions. The study was conducted in Academic Calendar Year 2020-2021.

\section{Sample}

Deans, teachers, and students of the Region III SUCs in the Philippines offering Teacher Education Programs were included as respondents of the study. The Yamane formula was used to compute the sample sizes needed to represent the teachers and students (Statistics How To, 2021). The sample size for teachers is 171 out of 316 total population and 344 for students out of 2,450 total population based on the deans' estimates. On the other hand, complete enumeration technique was used in considering the second set of respondents who comprised 10 deans and 10 chairs from the 10 TEIs of Region III SUCs.

\section{Instrument and Procedures}

Three sets of close-ended questionnaires were developed, validated, and transported to Google forms to gather data from the three sets of respondents. Open-ended questions were added to the questionnaire for the deans and chairpersons. In addition, the NTEC CMO documents and the curricular content offerings of the TEPs were obtained from the schools and were subjected to documentary analysis.

The three sets of questionnaires were validated by experts. The questionnaire for the deans and chairpersons (4.48) and teachers (4.45) got very satisfactory ratings from the experts. On the other hand, questionnaire for students had an excellent rating (4.57). Some experts had suggestions to improve the questionnaire and were considered in the final questionnaire transported to Google Forms for dry run. Data from the dry run were analyzed to establish reliability and validity. The questionnaire for teachers and deans and chairpersons got 0.96 Index of Reliability and 0.94 for the questionnaire intended for students. Both values indicate reliable and valid research tools.

After validation, the questionnaires were exported to Google Form for fast data gathering. The researchers sought help from the deans and chairpersons to share the link or URL to teachers and students. One-hundred percent response from the deans and chairpersons 
Alma M. CORPUZ, Teody C. SAN ANDRES, Julieta M. LAGASCA. Integration of environmental education (EE) in teacher education programs: Toward sustainable curriculum greening

PROBLEMS

OF EDUCATION

IN THE $21^{\text {st }}$ CENTURY Vol. 80, No. 1, 2022

124

was obtained within three days. For the teachers, 100\% response (171) was completed within a week and two weeks completion for students (344). Data from excel were downloaded and subjected to statistical analysis.

Research ethics was observed in conducting the study. The data gathered via Google Forms were carefully handled and the provisions of the Data Privacy Act of 2012 were observed by the researchers. Data extracted from the Google Forms were only accessed by the researchers and the statistician. The identities of the respondents were kept confidential. Moreover, the protocol was subjected for ethics review by the TSU-Research Ethics Review Committee. The research was given an ethical clearance certificate.

\section{Data Analysis}

After two weeks of online data gathering, the summarized data from excel was downloaded and subjected to statistical analysis using frequency, mean and Pearson ProductMoment Correlation Coefficient (Pearson's r). For qualitative data, mixed documents-based analysis technique and narrative analysis from open-ended questionnaires were employed. Carter et al. (2018) suggested the use of corroboration when dealing with qualitative data. Documents should be triangulated with interview and observation. In this study, curricular programs (prospectus) were requested to examine where EE was integrated. The course syllabi used by teachers were also requested to corroborate the responses in the open-ended questions.

\section{Research Results}

\section{Strategies in the Integration of Environment Education (EE) in Teacher Education Programs}

The analysis of the integration of EE in New Teacher Education Curricula (NTEC) was based on examining the CMO Nos. 74, and 75 series of 2017 (BEEd and BSEd, respectively); policies, guidelines, and programs; and in the teaching-learning process.

\section{Integration of EE in the Curricular Contents}

Integration of environmental education in the CMOs for BEEd and BSEd offered by the SUCs was analyzed. The strategies used in integrating environmental education in the NTEC were extracted from open-ended questions answered by the deans and chairpersons and by analyzing documents, which included the CMO No. 74, series of 2017 for Bachelor of Elementary Education (BEEd) and CMO No. 75, series of 2017, for Bachelor of Secondary Education (BSEd). The integration of EE in both programs was examined in statement of program outcomes, program indicators, and the curricular content (General Education Courses, Professional Education Courses Major/Specialization Courses and Mandated Courses). Copies of the two CMOs were downloaded from the CHED website and sample curricular contents were requested from two schools through the chairpersons.

Based on the data gathered, EE is integrated in the mandated courses NSTP and PE (all SUCs) and Environmental Science under the GE courses (for some SUCs). According to the interview with CP1a, in Physical Education, personal health, and community development included topics on EA. In NSTP, CP3 claimed that EA and action are integrated. During the face-to-face classes, activities of NSTP included tree planting and clean-up drive. However, these activities were suspended due to COVID-19 pandemic. Instead, webinars related to EA were attended by teachers and students. In addition, STS is a GE course included in the BEEd curriculum in all SUCs and in the CHED recommended Outcomes Based Teaching and 
Alma M. CORPUZ, Teody C. SAN ANDRES, Julieta M. LAGASCA. Integration of environmental education (EE) in teacher education programs: Toward sustainable curriculum greening

Learning (OBTL) for STS included topics on EA and CC. For BEEd program, EE is integrated mostly in GE and mandated courses.

As to the BSEd program, EE is also integrated in the General courses (STS) and mandated courses (PE and NSTP). But unlike the BEEd program, CMO No. 75, s of 2017 for the BSEd program clearly included statements about EE in program outcomes and performance indicators. For example, in BSEd in Social Studies, program outcomes were explicitly stated: (1) "To employ the principles of sustainable development in teaching and learning process" and the performance indicator is "Initiate advocacy campaigns towards the attainment of sustainable goals," "Organize initiatives for stewardships of natural resources," "Participate in activities that promote, and Integrate the environmental principles in teaching and learning."

Another evidence of EE integration is in the major courses of BSEd in Social Studies Human Geography, Physical Geography and Urban Geography. According to CP1b, the faculty member handling the course, they sponsored programs that promoted environmental awareness and action. Examples of the activities conducted were campaign against plastic use and Styrofoam; planting of trees and ornamental plants; and recycling waste to make decorations and bags. Summary of the integration of EE in the CMOs is shown in Appendix A.

Findings showed that in both BEEd and BSEd programs, EE was integrated in GE and mandated courses but not in professional and in major courses.

\section{Integration of EE through Policies and Memoranda and Guidelines}

Policies, memoranda, and guidelines to integrate EE in TEPs were also examined in this study and the results are reflected in Figure 1.

\section{Figure 1}

Policies, Programs and Guidelines Integrating EE in the TEPS

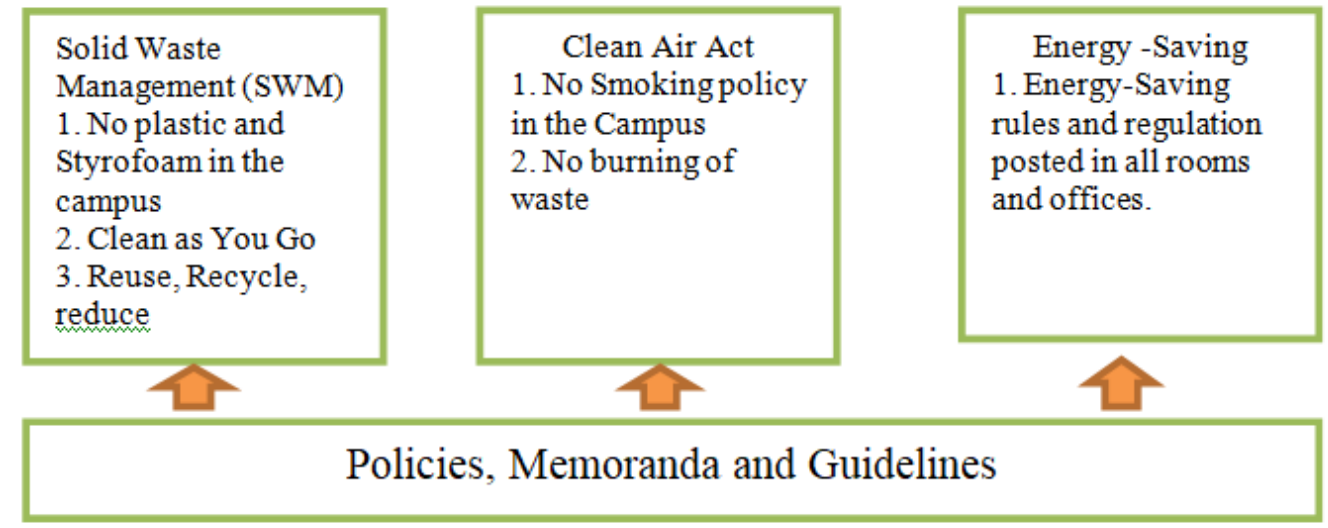

The policies, guidelines, and programs implemented in the SUCs were extracted from the open-ended questions for deans and chairpersons. The data from the respondents were grouped into three categories. The first category of EE programs is solid waste management. For this category, at least three were common among the SUCs. These were based on the response of all the deans and chairs (20 or 100\%). The first is "No Plastic and Styrofoam in the Campus." All employees, students, visitors, and other individuals are not allowed to bring in plastics or Styrofoam in all campuses. Canteen operators were also required to abide by the non-use of plastics, Styrofoam, and straws. Another program implemented in all schools is "Clean as You Go." In this program, students and other school stakeholders are expected to maintain 
Alma M. CORPUZ, Teody C. SAN ANDRES, Julieta M. LAGASCA. Integration of environmental education (EE) in teacher education programs: Toward sustainable curriculum greening

OF EDUCA

IN THE $21^{\text {st }}$ CENTURY Vol. 80 , No. 1,2022

126

cleanliness in school campuses. Additionally, labeled waste receptacles are in strategic areas in the school campuses in conformance to the proper waste segregation guideline of RA 9003, or the Ecological Solid Waste Management Program. Part of the SWMP is the practice of "reuse, recycle and reduce." All personnel and students were regularly encouraged to properly throw waste in designated bins to help the housekeeping personnel in waste segregation and disposal.

The second category of programs to support IEE is the "Clean Air Act of 1999." Here, schools imposed the "No Smoking Policy" and the "no burning of waste" guideline of the RA 9003. Signages were strategically posted near the entrance gates to ensure that the policies are known by everyone entering the school. Aside from entrance, signages were also posted in school buildings, classrooms, comfort rooms, and other strategic areas within the school campuses.

Lastly, schools practiced energy saving measures. Air conditioning units were only switched on at 9 A.M. and put off at 4:00 P.M. in offices and classrooms. Reminders to put off lights and other equipment when not in use were posted in all offices, classrooms, and other function rooms.

\section{Table 1}

Teachers' Strategies in Integrating EE in Teaching-Learning Process

\begin{tabular}{|c|c|c|c|}
\hline Strategies & Mean & $\begin{array}{l}\text { Standard } \\
\text { Deviation }\end{array}$ & $\begin{array}{l}\text { Verbal } \\
\text { Description }\end{array}$ \\
\hline $\begin{array}{l}\text { Open sharing in class on the effects of } \mathrm{CC} \text { and how each can } \\
\text { contribute to prevent future devastations due to man-made activities. }\end{array}$ & 4.1 & 0.95 & Often \\
\hline $\begin{array}{l}\text { Starting class sessions by sharing the need to perform roles in taking } \\
\text { care of the environment, such as following rules on waste management } \\
\text { inside the class, at home and wherever students are. }\end{array}$ & 3.81 & 0.97 & Often \\
\hline $\begin{array}{l}\text { Encouraging students to participate in community activities that } \\
\text { promote environmental care and awareness. }\end{array}$ & 3.78 & 1.01 & Often \\
\hline $\begin{array}{l}\text { Encouraging students to attend seminars, workshops and training } \\
\text { relative to environmental care and awareness. }\end{array}$ & 3.54 & 1.05 & Often \\
\hline $\begin{array}{l}\text { Participating in school-wide activities related to environmental } \\
\text { awareness. }\end{array}$ & 3.56 & 1.08 & Often \\
\hline $\begin{array}{l}\text { Integrating solid waste management (recycle, reuse, reduce and waste } \\
\text { segregation) in classroom. }\end{array}$ & 3.49 & 0.96 & Sometimes \\
\hline Including questions about current CC issues in assessments. & 3.46 & 1.05 & Sometimes \\
\hline Requiring news readings about current environmental problems. & 3.46 & 0.99 & Sometimes \\
\hline Integrating environment care and CC mitigation in syllabus. & 3.38 & 1.19 & Sometimes \\
\hline Requiring research activities on environment and CC. & 2.06 & 1.16 & Rare \\
\hline
\end{tabular}

Whenever devastating calamity strikes, teachers spared a time to talk about the calamity in class before proceeding to the lesson discussions (4.10). Teachers shared about the effects of climate change and challenged students to do their part in lessening activities that add to environment pollution and CC devastations. In addition, teachers often started class by challenging students to perform their roles in caring for the environment. Teachers 
Alma M. CORPUZ, Teody C. SAN ANDRES, Julieta M. LAGASCA. Integration of environmental education (EE) in teacher education programs: Toward sustainable curriculum greening

PROBLEMS

OF EDUCATION

IN THE $21^{\text {st }}$ CENTURY

Vol. 80 , No. 1,2022

reminded students to abide by solid waste management policies in school, at home, and in their communities (4.03). Teachers often reminded students to throw their waste properly in designated trash bins to facilitate waste segregation.

Moreover, teachers encouraged students to participate in school or community activities that promote environmental care and awareness like tree planting, clean up drive and others (3.56). Activities on environmental care were usually initiated in the NSTP; so, all students had experienced planting trees and clean-up drives. Teachers also encouraged students to attend seminars, workshops, and trainings relative to environmental care and awareness (3.54). In the past, students in TEPs joined seminars related to environmental awareness and care sponsored by other colleges but in the new normal, activities were more on webinars. In one of the SUCs, teacher CP2, shared that student organizations were active in joining webinars related to environmental awareness and care. Teacher CP2 related that the student organization members were active in joining the environment programs of the LGU where their school is located.

Another strategy was to encourage students to attend seminars, workshops, and trainings relative to environmental awareness and care (3.80) and participate in school-wide environmentrelated activities (3.80). Planting trees and other ornamental plants in school campuses and in communities was a common activity in all SUCs.

\section{University or College- Wide Programs that Integrate EE}

The deans and chairs were provided with open-ended questionnaire to ask about the programs or activities that they implemented in their respective colleges to support the integration of EE. The themes generated based on the data are shown in Figure 2.

\section{Figure 2}

The University or College - Wide Programs that Integrate EE

University and College -Wide Programs/Activities to Integrate EE in TE Programs

\begin{tabular}{|c|c|c|c|}
\hline $\begin{array}{l}\text { Extension } \\
\text { Programs }\end{array}$ & $\begin{array}{c}\text { College -based } \\
\text { Programs }\end{array}$ & Seminars/Webinars & $\begin{array}{c}\text { Campus /Virtual } \\
\text { Campaigns }\end{array}$ \\
\hline $\begin{array}{l}\text { Extension Programs of } \\
\text { faculty and students in } \\
\text { collaboration with LGUs } \\
\text { and tribal communities }\end{array}$ & $\begin{array}{c}\text { Student organizations' } \\
\text { Clean-up Drives, Tree } \\
\text { Planting }\end{array}$ & $\begin{array}{l}\text { Collaboration of TPEs with } \\
\text { other colleges on webinars } \\
\text { related to environmental } \\
\text { awareness and care }\end{array}$ & $\begin{array}{l}\text { Competitions to promote } \\
\text { environmental action }\end{array}$ \\
\hline
\end{tabular}

Extension programs of the SUCs included environmental care in their adopted communities. Usually, TEPs entered into Memorandum of Agreement (MOA) with the communities to conduct extension programs, which include EE. Examples of extension programs were providing seedlings to the adopted community members for backyard or pot gardening; environment education seminars; and organic farming. In addition, joint competitions to raise environmental awareness and action were also launched in all SUCs. In Bulacan State University, a Mangrove Project was part of their extension program in a community. The school was involved in coastal rehabilitation in cooperation with Wetlands International Philippines. 
Alma M. CORPUZ, Teody C. SAN ANDRES, Julieta M. LAGASCA. Integration of environmental education (EE) in teacher education programs: Toward sustainable curriculum greening IN THE $21^{\text {st }}$ CENTURY Vol. 80 , No. 1,2022 128
Support from the Management on the Integration of EE in TE Programs

The support of the management in IEE in teaching-learning process was determined based on the perception of the teachers and the data are shown in Table 2.

On the administrative support, teachers claimed that extension efforts (4.31) and research opportunities were promoted and supported (4.28). Trainings and seminars to enhance teachers' knowledge competence were provided and were opened to the teachers and students (4.16). During the pandemic, webinars were available and shared to all interested teachers and students. Moreover, release of Memoranda relative to the implementation of the new TEI curriculum, with emphasis to the promotion of environmental awareness was prompt and cascaded clearly to teachers (4.02). All memoranda from the management of most SUCs were posted in Facebook through the respective Public Affairs offices. However, incentives for exemplary accomplishments of targets relative to promotion of environmental awareness and climate change were fairly awarded since this was not consistently observed (2.90).

\section{Table 2}

Support in the Integration of EE in the Teaching -Learning Process

\begin{tabular}{|c|c|c|c|}
\hline IEE Support & Mean & $\begin{array}{l}\text { Standard } \\
\text { Deviation }\end{array}$ & $\begin{array}{l}\text { Verbal } \\
\text { Description }\end{array}$ \\
\hline \multicolumn{4}{|l|}{ A. Administrative Support } \\
\hline $\begin{array}{l}\text { Administrators support extension promoting environmental awareness (EA) and } \\
\text { climate change (CC). }\end{array}$ & 4.31 & 0.66 & Often \\
\hline Support to research opportunities promoting EA and CC. & 4.28 & 0.67 & Often \\
\hline Support to trainings and seminars promoting EA and CC. & 4.16 & 0.76 & Often \\
\hline $\begin{array}{l}\text { Prompt release of memoranda relative to the implementation of the new TEI } \\
\text { curriculum, with emphasis to EA and CC and cascading to teachers. }\end{array}$ & 4.02 & 0.77 & Often \\
\hline Incentives to exemplary accomplishments of targets to promote EA and CC. & 3.78 & 0.83 & Sometimes \\
\hline \multicolumn{4}{|l|}{ B. Physical/Material Support } \\
\hline Available and accessible vehicles for off-campus activities. & 4.07 & 0.88 & Often \\
\hline $\begin{array}{l}\text { Provision of Facilities and materials to complete extension activities to promote } \\
\text { EA and CC. }\end{array}$ & 4.03 & 0.85 & Often \\
\hline $\begin{array}{l}\text { Provision of facilities and materials needed to complete research in promotion of } \\
\text { EA and CC. }\end{array}$ & 2.56 & 0.87 & Often \\
\hline $\begin{array}{l}\text { Prompt provision of laboratory reagents and other needs for experiments related } \\
\text { to environment research. }\end{array}$ & 2.88 & 0.92 & Sometimes \\
\hline $\begin{array}{l}\text { Provision of Instructional Materials/Equipment to integrate topics on environment } \\
\text { and climate change by the management and other school stakeholders. }\end{array}$ & 2.78 & 0.93 & Sometimes \\
\hline \multicolumn{4}{|l|}{ C. Financial Support } \\
\hline $\begin{array}{l}\text { Management and other stakeholder's financial support for extension activities in } \\
\text { the promotion of EA and CC. }\end{array}$ & 4.13 & 0.84 & Often \\
\hline $\begin{array}{l}\text { Management and other stakeholder's financial support for research activities in } \\
\text { the promotion of EA and CC. }\end{array}$ & 4.10 & 0.66 & Often \\
\hline $\begin{array}{l}\text { Management and other stakeholder's financial support for curricular activities in } \\
\text { the promotion of EA and CC }\end{array}$ & 2.99 & 0.67 & Sometimes \\
\hline $\begin{array}{l}\text { Management and other stakeholder's financial support to acquire instructional } \\
\text { materials in the promotion of EA and CC. }\end{array}$ & 2.97 & 0.76 & Sometimes \\
\hline $\begin{array}{l}\text { Management and other stakeholder's financial support for physical arrangement } \\
\text { of classrooms in the promotion of EA and CC }\end{array}$ & 2.06 & 0.77 & Rare \\
\hline
\end{tabular}


Alma M. CORPUZ, Teody C. SAN ANDRES, Julieta M. LAGASCA. Integration of environmental education (EE) in teacher education programs: Toward sustainable curriculum greening

On physical or material support, teachers claimed that transport vehicles for off-campus activities were often available and accessible (4.07); facilities and materials needed to complete extension activities in the promotion of EA and $\mathrm{CC}$ (4.03) and to complete research relative to the promotion of EA and CC were provided in school (2.56). However, laboratory reagents and other needs for experiments were sometimes promptly provided (2.88). Teachers claimed that some experiments were not performed due to lack of materials.

As to financial support, teachers claimed regular support were provided for extension activities (4.13) and research (4.10). However, financial support to carry out class/school activities for the promotion of EA and CC (2.99) including financial support to acquire Instructional Materials (IMs) for the promotion of EA and CC (2.97), and financial support to improve physical classroom arrangement that supports EA and CC mitigation (2.06) were sometimes provided.

Findings revealed that administrative support for IEE in teaching-learning process gained positive feedback from the teachers but not in material and financial support. Feedback from teachers got means equivalent to "sometimes" response which indicates the belief of teachers that management support in these areas lacked consistency.

\section{Outcomes of Integration of EE in Teacher Education Program}

The outcomes of the integration of EE in TEPs were determined based on student feedbacks. Findings shown in Table 3 revealed that students often supported the "no smoking policy" in school or other public places (4.82); turned off lights when not in use (4.79); used water wisely (4.78); unplugged power cords and powered off computers or gadgets when not in use (4.74); threw waste in designated waste bins (4.64); often contributed to minimizing energy consumption bills to conserve energy (4.49); and used fans /blowers instead of air-conditioning units (4.49). In the campuses, reminders were posted in classrooms, stairs, pathways, bulletin boards in all buildings, and other places where students mostly spend their free time.

\author{
PROBLEMS \\ OF EDUCATION \\ IN THE $21^{\text {st }}$ CENTURY \\ Vol. 80 , No. 1,2022 \\ 129
}


Alma M. CORPUZ, Teody C. SAN ANDRES, Julieta M. LAGASCA. Integration of environmental education (EE) in teacher education programs: Toward sustainable curriculum greening

OF EDUCATION IN THE $21^{\text {st }}$ CENTURY Vol. 80 , No. 1,2022

130

Table 3

Outcomes /Applications of Integration of EE in Students' Knowledge Acquisition

\begin{tabular}{|c|c|c|c|}
\hline Knowledge acquisition Outcomes & Mean & $\begin{array}{l}\text { Standard } \\
\text { Deviation }\end{array}$ & $\begin{array}{l}\text { Verbal } \\
\text { Description }\end{array}$ \\
\hline Minimizing energy consumption for conservation. & 4.21 & 0.60 & Often \\
\hline Using fans /blowers instead of air-conditioning units. & 4.19 & 0.72 & Often \\
\hline Not burning leaves, trash, and other materials. & 4.15 & 0.85 & Often \\
\hline Using public transportation or carpooling. & 4.09 & 0.70 & Often \\
\hline Replacing incandescent light bulbs with compact fluorescent or LED. & 4.02 & 0.53 & Often \\
\hline Purchasing energy-efficient appliances. & 4.01 & 0.49 & Often \\
\hline Supporting the "no smoking policy" in school or other public places. & 3.81 & 0.57 & Often \\
\hline Turning off the lights when not in use. & 3.79 & 0.84 & Often \\
\hline Using water wisely at home. (e.g. conserving water) & 3.61 & 0.82 & Often \\
\hline $\begin{array}{l}\text { Unplugging power cords and power off computers or gadgets when not in } \\
\text { use. }\end{array}$ & 3.54 & 0.70 & Often \\
\hline Disposing off or handle hazardous waste properly. & 3.35 & 0.78 & Sometimes \\
\hline Reusing, recycling, and reducing waste materials. & 3.21 & 0.92 & Sometimes \\
\hline Planting trees or vegetables to contribute to greening the environment. & 3.19 & 0.49 & Sometimes \\
\hline Throwing waste in designated bins. & 3.15 & 0.75 & Sometimes \\
\hline Biking or walking to avoid carbon emissions, & 3.02 & 0.85 & Sometimes \\
\hline Not using plastics or Styrofoam. & 2.86 & 0.81 & Sometimes \\
\hline Eating less meat. & 2.78 & 0.78 & Sometimes \\
\hline Turning food and garden waste into composts. & 2.21 & 0.88 & Rare \\
\hline
\end{tabular}

Moreover, students claimed that they avoided burning leaves, trash, and other materials (4.47); disposed or handled hazardous waste properly (4.46); used public transportation or carpooling (4.39); replaced incandescent light bulbs with compact fluorescent or LED (4.30); purchased energy-efficient appliances or advised parents to do it (4.28); refrained from using plastics or Styrofoam and supported eco-friendly materials (4.09); and preferred less meat for meals (4.03). Students were aware of the LGU ordinances about burning of waste. At home, some students were conscious about purchasing equipment or materials that are eco-friendly.

However, students were not consistent in reducing, re-using, reduction of waste materials (3.43); planting trees or vegetables to contribute to greening the environment (3.37); using bicycles, or walking to avoid carbon emissions (3.20); and they rarely turned food and garden waste into composts (2.21). Despite students' knowledge on solid waste management, lack of personal application as manifested from their responses in the questionnaire, was apparent. Also, they were knowledgeable of the principle of composting, but they rarely applied it at home. 
Alma M. CORPUZ, Teody C. SAN ANDRES, Julieta M. LAGASCA. Integration of environmental education (EE) in teacher education programs: Toward sustainable curriculum greening

Table 4

Outcomes /Applications of Integration of EE in Students'Skills Acquisition

\begin{tabular}{|c|c|c|c|}
\hline Skills acquisition Outcomes & Mean & $\begin{array}{l}\text { Standard } \\
\text { Deviation }\end{array}$ & $\begin{array}{l}\text { Verbal } \\
\text { Description }\end{array}$ \\
\hline $\begin{array}{l}\text { Making eco-friendly cleaning solutions (home-made- e.g., use of vinegar } \\
\text { and soda in soaking soiled clothes) }\end{array}$ & 3.21 & 0.82 & Sometimes \\
\hline Putting up vertical garden at home and in ecofriendly pots. & 3.21 & 0.94 & Sometimes \\
\hline Making cloth napkins. & 3.20 & 0.86 & Sometimes \\
\hline Making decorations out of recyclable waste. & 3.15 & 0.99 & Sometimes \\
\hline Making eco-friendly bags from recyclable materials. & 1.96 & 1.03 & Rare \\
\hline $\begin{array}{l}\text { Developing kitchen materials from eco-friendly materials (e.g., bamboo } \\
\text { sipping tools than plastic straws; bowls made of bamboo than plastic } \\
\text { bowls). }\end{array}$ & 1.78 & 1.19 & Rare \\
\hline $\begin{array}{l}\text { Making trash bins with proper labels to throw waste at home (e.g., non- } \\
\text { biodegradable or biodegradable waste) }\end{array}$ & 1.56 & 1.08 & Rare \\
\hline Crafting wooden toys for younger siblings or nephews and nieces. & 1.56 & 1.24 & Rare \\
\hline Making furniture from eco-friendly materials. & 1.51 & 1.16 & Rare \\
\hline Using eco-friendly light source. & 1.50 & 1.27 & Rare \\
\hline
\end{tabular}

Students had not regularly applied the skills they learned from their attendance to EE activities. Making eco-friendly cleaning solutions (home-made- e.g., use of vinegar and soda in soaking soiled clothes) (3.21), vertical gardening at home and using ecofriendly pots (3.21), using cloth napkins (3.20), and making decorations out of recyclable waste (3.15) were only "sometimes" done.

On rare occasions, students made eco-friendly bags from recyclable materials (1.96), kitchen materials from eco-friendly materials (e.g., bamboo sipping tools than plastic straws; bowls made of bamboo than plastic bowls) (1.78); trash bins with proper labels at home (e.g., non-biodegradable or biodegradable waste) (1.56); wooden toys for younger siblings or nephews and nieces (1.56); furniture from eco-friendly materials (1.51); and eco-friendly light source (1.50).

Again, findings on the outcomes of skills acquired by the students IEE, showed weak results as the feedback from the students manifested inconsistent application in their personal lives.

As to the outcome of the integration of EE on attitude, Table 5 shows that students believed they have important role in keeping the environment healthy (4.52) and were convinced that they can participate in solving negative effects of climate change (4.44). Students believed they became responsible in promoting environmental care in community (4.38) and had taken action to keep the natural world healthy (4.37). They were also enthusiastic supporters of activities for regreening efforts (4.37). The positive response of the students to these indicators could be attributed to their active participation in school/college-sponsored activities. The students developed a more ecological-friendly lifestyle (4.23) and they related well with the elements of the environment (4.13). However, students' response on their passion for greening activities (3.17) and in assuming leadership role to advance environmental protection (2.84), showed lower mean ratings. Apparently, involvement in these activities was only in fulfilling school requirements. 
Alma M. CORPUZ, Teody C. SAN ANDRES, Julieta M. LAGASCA. Integration of environmental education (EE) in teacher education programs: Toward sustainable curriculum greening

OF EDUCA

IN THE $21^{\text {st }}$ CENTURY Vol. 80 , No. 1, 2022

132

Table 5

Outcomes of Integration of EE in Students' Attitude

\begin{tabular}{|c|c|c|c|}
\hline Outcomes on Attitude & Mean & $\begin{array}{l}\text { Standard } \\
\text { Deviation }\end{array}$ & Verbal Description \\
\hline $\begin{array}{l}\text { Being convinced of their important role in keeping the } \\
\text { environment healthy. }\end{array}$ & 4.52 & 0.75 & Always \\
\hline $\begin{array}{l}\text { Believing that something can be done to solve negative } \\
\text { effects of climate change. }\end{array}$ & 4.44 & 0.74 & Often \\
\hline $\begin{array}{l}\text { Becoming responsible in promoting environmental care in the } \\
\text { community. }\end{array}$ & 4.38 & 1.06 & Often \\
\hline Taking action to keep the natural world healthy. & 4.37 & 0.83 & Often \\
\hline Being an enthusiastic supporter of greening activities. & 4.37 & 0.85 & Often \\
\hline $\begin{array}{l}\text { Developing confidence and good stewardship of the } \\
\text { environment. }\end{array}$ & 4.35 & 0.83 & Often \\
\hline Having a more ecological-friendly lifestyle. & 4.23 & 0.70 & Often \\
\hline Relating well with the elements of the environment. & 4.13 & 0.75 & Often \\
\hline Being passionate on greening activities. & 3.17 & 0.74 & Sometimes \\
\hline $\begin{array}{l}\text { Becoming a leader in advancing the cause of environmental } \\
\text { protection. }\end{array}$ & 2.84 & 1.06 & Sometimes \\
\hline
\end{tabular}

Correlation of Student Knowledge Outcomes and Attitude Outcomes of IEE

The knowledge and skill outcomes were related with the attitude of the students on environment. The Pearson's $r$ and $p$ values are shown in Table 6.

Table 6

Correlation of Students' Knowledge and skills outcomes to their attitude

\begin{tabular}{lllll}
\hline Variable & Pearson's $r$ & $p$ value & Decision & Interpretation \\
\hline $\begin{array}{l}\text { Knowledge and } \\
\text { Attitude }\end{array}$ & $.593^{\star *}$ & .001 & Reject Ho & Significant \\
\hline Skills and Attitude & $.647^{* *}$ & .001 & Reject Ho & Significant \\
\hline
\end{tabular}

Note: $* *$ Correlation is significant at the 0.05 level (2-tailed)

Pearson's $r$ value of 0.593 and $p$ value $<.05$ significance level show that knowledge and attitude are significantly related. This means that the more knowledgeable the students were on $\mathrm{EE}$, the better is their attitude. Likewise, Pearson's $\mathrm{r}$ value of .647 and $p$ value $<0.5$ significance level indicates significant relationship between skills acquisition and attitude of the students.

\section{Challenges in the Integration of EE in TE Programs}

Table 7 shows the challenges of the teachers in integrating environmental education in teaching and learning. 
Alma M. CORPUZ, Teody C. SAN ANDRES, Julieta M. LAGASCA. Integration of environmental education (EE) in teacher education programs: Toward sustainable curriculum greening

Table 7

Challenges in the Integration of EE in TE Programs

\begin{tabular}{|c|c|c|}
\hline Challenges Encountered & $f$ & $\%$ \\
\hline Inadequate knowledge about EE. & 100 & 56.50 \\
\hline $\begin{array}{l}\text { Inadequate time to allow activities for students that could have increased their } \\
\text { environment literacy and involvement. }\end{array}$ & 93 & 52.54 \\
\hline Unclear guidelines from the management on how to integrate EE. & 76 & 42.94 \\
\hline Lack of memorandum or circulars from CHED or DepED regarding the integration of EE. & 70 & 39.55 \\
\hline Inadequate stakeholders' support from the management to integrate EE. & 60 & 33.90 \\
\hline Inadequate strategies to integrate EE into the curriculum. & 58 & 32.77 \\
\hline Integration of EE is not a priority program supported in the school. & 49 & 27.68 \\
\hline $\begin{array}{l}\text { Lack of leadership to motivate the school stakeholders to strengthen the integration of EE } \\
\text { in the curriculum. }\end{array}$ & 46 & 25.99 \\
\hline Lack of learning resources to integrate EE extensively. & 38 & 21.47 \\
\hline $\begin{array}{l}\text { Teachers' heavy load that hinders more engaging activities to integrate EE in the } \\
\text { curriculum. }\end{array}$ & 33 & 18.64 \\
\hline
\end{tabular}

Challenges of teachers in IEE were inadequate knowledge about EE (56.50\%); lack of time to do activities with students that could have increased their environment literacy and involvement (52.54\%); and heavy workloads which hindered their time in engaging activities to integrate $\mathrm{EE}$ in the curriculum (18.64\%). In addition, lack of clear guidelines from the management on how to integrate EE (42.94\%) and lack of memorandum or circulars from CHED or DepED (39.55\%) were perceived to have affected their IEE. Likewise, there was a lack of support from the management to integrate EE (33.90\%).

Another problem encountered was the lack of knowledge on effective strategies to integrate EE into the curriculum (32.77\%). Teachers also claimed that IEE was not a priority program supported in the school $(27.68 \%)$. Leadership to motivate the school stakeholders to strengthen the integration of EE in the curriculum (25.99) and learning resources to integrate EE extensively (21.47\%) were also inadequate.

Proposed Enhancements to Fully Integrate EE in the TEPS

Based on the findings, the proposed enhancements in the integration of EE in the TEIs are shown in Table 8. The SUCs offering TEPs may adopt the program. 
Alma M. CORPUZ, Teody C. SAN ANDRES, Julieta M. LAGASCA. Integration of environmental education (EE) in teacher education programs: Toward sustainable curriculum greening

OF EDUCAT

IN THE $21^{\text {st }}$ CENTURY

Vol. 80 , No. 1,2022

134

Table 8

Proposed Enhancements to Fully Integrate EE in the TEPS

\begin{tabular}{|c|c|c|c|}
\hline Objectives & Strategies/Programs/Activities & $\begin{array}{l}\text { Resources / } \\
\text { Persons involved }\end{array}$ & Expected Result \\
\hline \multicolumn{4}{|l|}{ Curriculum Content } \\
\hline $\begin{array}{l}\text { To enhance IEE in program } \\
\text { outcomes and performance } \\
\text { indicators for the BEEd } \\
\text { curriculum }\end{array}$ & $\begin{array}{l}\text {-An explicit statement on EA } \\
\text { and action similar to the BSEd } \\
\text { curriculum may be included. }\end{array}$ & $\begin{array}{l}\text { Curriculum } \\
\text { developers }\end{array}$ & $\begin{array}{l}\text { Program Outcomes in the } \\
\text { BEEd curriculum include } \\
\text { statements on EA and care. }\end{array}$ \\
\hline \multirow[t]{2}{*}{$\begin{array}{l}\text { To add or retain EE in the } \\
\text { GE courses in the BEEd } \\
\text { program. }\end{array}$} & $\begin{array}{l}\text {-EE was present in the CMO } \\
\text { No. } 30 \text {, series of } 2004 \text { under the } \\
\text { Special Topics but was no longer } \\
\text { recommended in the CMO No. } \\
74 \text {, series of } 2017 \text { curriculum. }\end{array}$ & $\begin{array}{l}\text { Curriculum } \\
\text { Developers } \\
\text { Respective school's } \\
\text { Program Deans, } \\
\text { Chairs and Faculty }\end{array}$ & $\begin{array}{l}\text { EE is retained in the } \\
\text { New Teacher Education } \\
\text { Curriculum }\end{array}$ \\
\hline & & $\begin{array}{l}\text { Respective school's } \\
\text { Program Deans, } \\
\text { Chairs and Faculty }\end{array}$ & \\
\hline
\end{tabular}

To integrate $\mathrm{EE}$ in professional courses for both BEEd and BSEd, particularly in the OBTLs where learning environment is discussed.
Strategic inclusion of EE under the management of teachinglearning environment in the OBTLS
Respective school's Program Deans, Chairs and Faculty
$E E$ is a part of the Professional Courses in discussion of teachinglearning environment
To add EE in other BSEd majors, not only in BSEd Social Studies.
Environmental Education may be added in the GE courses in other BSEd curriculum.
Respective school's

Program Deans,

Chairs and Faculty
EE is a part of the General Education Courses in BSEd Curriculum

Integration of EE Support

\begin{tabular}{|c|c|c|c|}
\hline $\begin{array}{l}\text { Allot budgetary support for } \\
\text { IEE in the TEPs. }\end{array}$ & $\begin{array}{l}\text { Budget for integration of EE in } \\
\text { the TEPs may be provided and } \\
\text { must trickle down to the faculty } \\
\text { members. }\end{array}$ & $\begin{array}{l}\text { CHED, DBM, SUC } \\
\text { presidents and } \\
\text { Budget Officers }\end{array}$ & $\begin{array}{l}\text { Budget to integrate EE in the } \\
\text { BEEd and BSEd programs } \\
\text { is adequate. }\end{array}$ \\
\hline $\begin{array}{l}\text { To include webinars/ } \\
\text { seminars on integration of } \\
\text { EE in the teaching -learning } \\
\text { process in the Faculty } \\
\text { Development programs. }\end{array}$ & $\begin{array}{l}\text { SUCs may include webinars/ } \\
\text { seminars and workshops for } \\
\text { TEP faculty members to equip } \\
\text { them with competencies for } \\
\text { effective IEE. }\end{array}$ & $\begin{array}{l}\text { Human Resources } \\
\text { Deans } \\
\text { Faculty members } \\
\text { Resource speakers }\end{array}$ & $\begin{array}{l}\text { Faculty members are fully } \\
\text { equipped and competent } \\
\text { in IEE. }\end{array}$ \\
\hline $\begin{array}{l}\text { Collaborate with school } \\
\text { stakeholders for support } \\
\text { to IEE. }\end{array}$ & $\begin{array}{l}\text { Deans of TPEs may seek } \\
\text { collaboration with school } \\
\text { stakeholders for support in full } \\
\text { IEE in BSEd and BEEd curricula. }\end{array}$ & $\begin{array}{l}\text { Deans } \\
\text { Faculty members }\end{array}$ & $\begin{array}{l}\text { School Stakeholders other } \\
\text { than management, faculty } \\
\text { and teachers such as LGUs, } \\
\text { community and parents are } \\
\text { actively collaborating in IEE. }\end{array}$ \\
\hline
\end{tabular}

\section{Discussion}

Findings of the study showed that EE is integrated in the New Teacher Education Curriculum in both the BEEd and BSEd programs as shown in the implementation of the SUCs of 
the Policies, Standards and Guidelines provided in the CMO Nos. $74 \& 75$, s. 2017. The program ensuring advocacy campaigns towards the attainment of sustainable goals, initiating stewardships of natural resources, participating in activities that promote environmental consciousness, and in integrating the environmental principles in teaching and learning. Similarly, the BSEd in Values Education, include planning and managing community development programs for values enhancement of the people in the community in the performance indicators. However, in the BEEd curriculum, there were no statements in the program outcomes and performance indicators that explicitly supported the EE integration. This is also true to some BSEd majors. Since EE is construed to transformative learning opportunities (North American Association for Environmental Education, n.d.), it must be a part of all educational programs.

In terms of the curriculum content, the mandated courses - PE and NSTP, included lessons intended to increase EA of students and encourage them to join environmental action. Moreover, STS is included in the General Education Courses in both the BEEd and BSEd programs in most SUCs and part of the STS content, lessons on EA, biodiversity and climate change were included. In BEEd curriculum, Environmental Science is a General Education course included in some SUCs. In the BSEd in Social Studies program, a major course, Human Geography, Physical Geography and Urban Geography heavily discusses EE and students taking up the course were led by the faculty in spearheading activities that promote environmental awareness and care.

In terms of the integration of EE in the teaching-learning process, teachers often reminded students to follow guidelines and laws related to environmental care such as abiding with solid waste management. Also, teachers took time to share about environment problems and issues whenever calamities occurred. Teachers claimed that these were opportune times to increase environmental awareness and care of the students.

As to the policies and guidelines that support the integration of EE in the TEPs, findings revealed that these were observed in all SUCs. The solid waste management program was strictly imposed in schools and the "no-smoking" policy, was a clear support to the "Clean Air Act "Law from the government. Energy-saving guidelines were also being instituted in schools.

The findings that showed lack of financial support for the integration of EE in schools were consistent with the findings of the study conducted by Mwenda (2017) in Tanzania where one of the teachers' challenges was lack of support from each other and from the administration. The same findings were also shown in the study of Rahman et al. (2018) in Malaysia.

On the outcomes of the integration of the EE in the TEPs, students showed consistent positive attitude, except for developing passion for greening activities and leadership. Knowledge and skills application in real life settings, need improvement. The positive attitude of students in terms of environmental care are consistent with the results in the study of Erhabor and Don (2016) in Nigeria showing high level of students' attitude in environmental care but a negative relationship between the knowledge and attitude was found. The authors recommended the need to promote and encourage the integration of EE in all educational levels in Nigeria. Likewise, Edsand and Broich (2019) found that EE had a weak effect to the environmental awareness and action among the students and recommended the need for more enhancements.

Another finding of the study is the positive correlation of knowledge (moderate) and skills (high) to the attitude of the students. These are manifestations of the need to intensify environmental education to see positive results on the students' attitude.

As to the challenges encountered by teachers in the integration of EE in the curriculum, the most pressing ones were inadequate knowledge about EE; lack of time to allow activities for students that could have increased their environment literacy and involvement; and lack of clear guidelines from the management on how to integrate educational environment. According to some teachers, they have other responsibilities aside from teaching that limits their involvement 
Alma M. CORPUZ, Teody C. SAN ANDRES, Julieta M. LAGASCA. Integration of environmental education (EE) in teacher education programs: Toward sustainable curriculum greening

PROBLEMS

OF EDUCATION IN THE $21^{\text {st }}$ CENTURY Vol. 80 , No. 1,2022

in environmental action. These findings are consistent with the result of Marpa (2020) in a study in Philippine Normal University of Visayas- that among the challenges encountered in the integration of EE were the lack of curriculum materials, teaching competencies, and time. The challenges of the teachers in integrating EE in the curriculum were also similar to the findings of Benjamin and Adu (2019) in South Africa. Hence, the authors recommended for the development of curriculum with clear goals and the content with specific guidelines which shall develop teachers' capacity in integrating environmental education. Successful implementation of any educational policy largely depends on the teachers' competencies and support.

\section{Conclusions and Implications}

Environmental Education is integrated in the NETC based on the results and discussions presented in this study. The integration is clearly observed in curricular contents, especially in General Education courses and Mandated courses. Policies, guidelines, and programs are likewise apparent in all programs and supported by the administration. Faculty and students alike launch and participate in programs that promote environmental awareness and action. Teachers include EE in the teaching-learning process. However, program outcomes and performance indicators still lacked statements supporting EE, especially in the BEEd program. In addition, on the learning outcomes or the students' ability to apply the EE knowledge and skills in the real -life setting, findings imply the need to enhance integration strategies in such a way that students are not only active in attending school programs but also in applying what they learned in school at home and in their respective communities. Findings imply that EE integration in curricular programs help in promoting environmental knowledge, skills and attitude among students but involving other stakeholders, especially the family and the community are also needed so that application beyond school or classrooms is ensured. The study then recommends that schools should involve all stakeholders, especially families, in EE.

Moreover, results of the study have implications to the integration of EE in educational curricula across countries in the world. Since environmental problems are global, world leaders need to work together in addressing these interconnected global challenges. The results of the present study and the proposed enhancement of curricular programs may be significant inputs to the plans and strategies of countries in the world in their attempt to intensify integration of environmental education in their respective curricula, to achieve sustainability.

\section{Recommendations}

School administrators and teachers must institute better strategies to influence student application of knowledge and skills acquired from environmental education beyond classroom or school. The results of the study showed that involvement of students in environmental action were only tied to their school requirements but not in their personal lives. Teachers may consider requiring students to submit portfolios or journals on how they apply their EE knowledge and skills acquisition at home. Teachers may also ask students to develop reflection papers on environmental issues and the possible practical solutions. These activities will enable higher student engagement in environmental action, not only in school but also at home and in the communities. As to the teachers' challenges in IEE, giving thorough orientation and capability building activities are viable solutions.

The intervention measures proposed in this study maybe considered by curriculum developers, school heads/presidents/directors and teachers of all educational institutions across countries in the globe to strengthen the integration of EE in their respective curricular offerings. Future studies may explore the hindrances or factors that limit students' application of their learning acquisition in real-life settings. 
Alma M. CORPUZ, Teody C. SAN ANDRES, Julieta M. LAGASCA. Integration of environmental education (EE) in teacher education programs: Toward sustainable curriculum greening

\section{Acknowledgement}

The authors express their gratitude to the management of Tarlac State University, through the president, Dr. Myrna Q. Mallari and Bulacan State University, through Dr. Cecila S. Navasero-Gascon, the president, for the support and funding for the research.

\section{Declaration of Interest}

The authors declare no competing interest.

\section{References}

Abun, D. (2017). Environmental attitude and environmental behavior of Catholic Colleges' Employees in Ilocos Sur, Philippines. Texila International Journal of Academic Research, 4(1), 1-30. https://doi.org/10.21522/TIJAR.2014.04.01

Benjamin, D., \& Adu, E. O. (2019). Challenges teachers face in the integration of Environmental Education into the South African curriculum. American Journal of Humanities and Social Science Research (IJHSSR), 03(10), 157-166.

Boquet Y. (2017). Environmental challenges in the Philippines. In: The Philippine Archipelago (pp. 779821). Springer Geography. https://doi.org/10.1007/978-3-319-51926-5_22

Carter, N., Bryant-Lukosius, D., DiCenso, A., Blythe, J., \& Neville, A. J. (2014). The use of triangulation in qualitative research. Oncology Nursing Forum, 41(5), 545-547. https://doi.org/10.1188/14.ONF.545-547

Climate Change Commission (2011). National Climate Change Commission 2001-2018. http://extwprlegs 1.fao.org/docs/pdf/phi152934.pdf

Commission on Higher Education (2017). CMO No.75, s. of 2017. https://ched.gov.ph/wpcontent/ uploads/2017/11/CMO No.-75-s

Commission on Higher Education (2017). CMO No.75, s. of 2017.

Commission on Higher Education (2016). CHED Memorandum Order 52, s of 2016. https://ched.gov.ph/ wpcontent/uploads/2017/10/CMO-52-s.-2016.pdf

Commission on Higher Education (2012). CHED Initiatives in Strategizing HEIs for Climate Change Adaptation. http://119.92.161.2/portal/Portals/20/Patlepam/Powerpoints/asian\%20educators/ RSS_CHED\%20Initiatives\%2on\%20Climate\%20Change_5November2013.pdf

Commonwealth of Education Hub (2020). The role of education in propelling climate action. https:// www.thecommonwealth-educationhub.net/the-role of-education-in-propelling-climate-action/

Commission on Higher Education (2009). CHED Memorandum Order No. 33, series of 2009. https://ched.gov.ph/wp-content/uploads/2017/10/CMO-No.33-s2009.pdf

Department of Education (2021). DepEd creates microsite for teaching climate change. https://www. deped.gov.ph/2021/03/08/deped-creates-microsite-for-teaching-climate-change/

Department of Education (2020). DepEd eyes strengthening of climate change awareness in basic education. https://www.deped.gov.ph/2020/12/16/deped-eyes-strengthening-of-climate-changeawareness-inbasiceducation

Department of Education (2018). DM 019, s. 2018 - 2018 Activities of the Department of Environment and Natural Resources. https://www.deped.gov.ph/2018/02/07/dm-019-s-20182018-activitiesofthedepartment-ofenvironment-and-natural-resources/

Department of Education. (2011). DO No. 52, series of 2011. https://www.deped.gov.ph/2011/07/05/ do52-s-2011strengthening-environmental-education-in-public-and-private-schools/

Department of Education (2011). Strengthening Environmental Education in Public and Private Schools. https://www.deped.gov.ph/2011/07/05/do-52-s-2011-strengthening-environmentaleducation-inpublicand-private-schools/

DepED (n.d.). Vision, mission and core values. https://www.deped.gov.ph/aboutdeped/visionmissioncore-valuesand-mandate/

Department of Environment and Natural Resources (2019). DENR Secretary's Speech. http://www. r5.denr.gov.ph/news-and-features/latest-news/3043-secretary-roy-a-cimatus-speeches.html 
Alma M. CORPUZ, Teody C. SAN ANDRES, Julieta M. LAGASCA. Integration of environmental education (EE) in teacher education programs: Toward sustainable curriculum greening

PROBLEMS

OF EDUCATION IN THE $21^{\text {st }}$ CENTURY Vol. 80 , No. 1,2022

138

Environmental Management Bureau (n.d.). Youth Program. http://eeid.emb.gov.ph/?page_id=228

Environmental Protection Agency (2018). What is environmental protection? https://www.epa.gov/ education/whatenvironmentaleducation\#: :text=Environmental $\% 20$ education $\% 20$ is $\% 20 \mathrm{a} \% 20$ process,make\%20informed $\% 20$ nd $\% 20$ responsible $\% 20$ decisions

Erhabor, E. I., \& Don, J. U. (2016). Impact of environmental education on the knowledge and attitude of students towards the environment. International Journal of Environmental \& Science Education, 11(12), 5367-5375. https://files.eric.ed.gov/fulltext/EJ1115646.pdf

Garcesa, R. D., \& Limjuco, R. P. (2014). Environmental literacy and integration of environmental issues among Science teachers in Region X1: Basis for training design. UIC Research Journal, 20(1), 207-225. https://ejournals.ph/article.php?id=13163

Global Climate Change (2021). The effects of climate change. https://climate.nasa.gov/effects/

Hershberger, M. (2014). 6 environmental challenges facing Southeast Asia (and what you can do to help). https://matadornetwork.com/change/6-environmental-challenges-facing-southeast

Labog, R. A. (2017). Teachers' integration of environmental awareness and sustainable development practices. Asia Pacific Journal of Multidisciplinary Research, 5(3), 102-110. http://www.apjmr. com/wpcontent/uploads/2017/08/APJMR-2017.5.3.2.14.pdf

Malipot, M. (2019, April 6). Search for sustainable, eco-friendly schools launched. Manila Bulletin. https://mb.com.ph/2019/04/06/search-for-sustainable-eco-friendly-schools-launched/

Mandel, P. (2018). Children as change agents: The influence of integrating environmental education into home learning projects on families and community members. Digital Commons, 75-79. https://core.ac.uk/download/pdf/46946326.pdf

Marpa, E. (2020). Navigating environmental education practices to promote environmental awareness and education. International Journal on Studies in Education, 2(1), 45-57. https://www.ijonse.net/ index.php/ijonse/article/view/8/pdf

Mwendwa, B. (2017). Learning for sustainable development: Integrating environmental education in the curriculum of ordinary secondary schools in Tanzania. Journal of Sustainability Education, 12, 1-15. http://www.susted.com/wordpress/wp-content/uploads/2017/02/Mwendwa-JSE-Feb-2017GenerIssuePDF.pdf

National Education Association [(NEA), 2020]. Climate Change Education: Essential Information for Educators. https://www.nea.org/professional-excellence/studentengagement/tools-tips/climatechangeeducationessential

North American Association for Environmental Education (n.d.). The Benefits of Environmental Education for K-12 Students. https://naaee.org/eepro/research/eeworks/student-outcomes

Perez, R. B., \& Bua, Jr., V. E. (2019). Greening the curriculum for sustainable development. Education Resources Information Center (ERIC) Data base. 1-15. https://files.eric.ed.gov/fulltext/ED600473. pdf

Rahman, N., Halim, L., Ahmad, A., \& Soh, T. (2018). Challenges of environmental education: Inculcating behavioural changes among indigenous students. Creative Education, 9, 43-55. https://doi.org/10.4236/ce.2018.91004

Sustainable Development Goals (2020). About the Sustainable Development Goals. https://www.un.org/ sustainabledevelopment/sustainable-development-goals/

Statistics How To (2021). Sample size in statistics (How to find it): Excel, Cochran's formula, general tips. https://www.statisticshowto.com/probability-and-statistics/find-sample-size

Tsui, J. (2020). Five Biggest Environmental Issues Affecting the U.S. Five Biggest Environmental Issues Affecting the U.S. Environmental Protection, 1. https://eponline.com/Articles/2020/02/24/FiveBiggest-Environmental-Issues-Affecting-the-US.aspx?Page $=1$

United Nations Educational, Scientific, and Cultural Organization, n.d.). Climate Change Education and Awareness. https://en.unesco.org/themes/addressing-climate-change/climatechange-educationandawareness\#: : text=Education $\% 20$ is $\% 20 \mathrm{an} \% 20$ essential $\% 20$ element,to $\% 20$ climate $\% 20$ change20related\%20trends

United Nations Educational Scientific and Cultural Organization (UNESCO, 2019). Climate Change Education. https://en.unesco.org/

United Nations (2020). The Climate Crisis - A Race We Can Win. https://www.un.org/en/un75/climatecrisis-race-wecan-win 
Alma M. CORPUZ, Teody C. SAN ANDRES, Julieta M. LAGASCA. Integration of environmental education (EE) in teacher education programs: Toward sustainable curriculum greening

United States Agency for International Development (USAID, 2019). Environment. https://www.usaid. gov/philippines/energy-and-environment

Velimpini, K. (2016). The integration of environmental education in the secondary school curriculum: A case study of a 10th grade junior secondary school curriculum in the Okavango Delta, Botswana. https://etd.ohiolink.edu/!etd.send_file?accession=ohiou1451919034\&disposition=inline

Verma, G., \& Dhull, P. (2017). Environmental education as subject in schools. International Journal of Advanced Research (IJAR), 5(8), 1547-1552. http://dx.doi.org/10.21474/IJAR01/5214

\section{Appendix A}

Integration of EE Vis-à-vis the Policies, Standards and Guidelines provided in the CMO Nos. 74 \&75, s. 2017

\begin{tabular}{|c|c|c|c|c|c|}
\hline Program & $\begin{array}{l}\text { General Educa- } \\
\text { tion Courses }\end{array}$ & $\begin{array}{l}\text { Majorl } \\
\text { Specialization } \\
\text { Courses }\end{array}$ & $\begin{array}{l}\text { Mandated } \\
\text { Courses }\end{array}$ & Program Outcomes & $\begin{array}{l}\text { Performance } \\
\text { Indicators }\end{array}$ \\
\hline $\begin{array}{l}\text { Bachelor in } \\
\text { Elementary } \\
\text { Education }\end{array}$ & $\begin{array}{l}\text { Science, Technol- } \\
\text { ogy and Society } \\
\text { (STS) } \\
\text { Learning } \\
\text { Outcome under } \\
\text { values: "Foster } \\
\text { the value of a } \\
\text { healthy lifestyle } \\
\text { toward the holistic } \\
\text { and sustainable } \\
\text { development of } \\
\text { society and the } \\
\text { environment" } \\
\text { (CHED, 2013) } \\
\text { Environmental } \\
\text { Science } \\
\text { (in some SUCs) }\end{array}$ & $\begin{array}{l}\text { Teaching } \\
\text { Science in } \\
\text { the Elemen- } \\
\text { tary Grades } \\
\text { (Biology and } \\
\text { Chemistry) } \\
\text { Teaching } \\
\text { Science in the } \\
\text { Elementary } \\
\text { Grades (Phys- } \\
\text { ics, Earth, } \\
\text { and Space } \\
\text { Science) }\end{array}$ & $\begin{array}{l}\text { NSTP } \\
\text { CMO No. } \\
33 \text {, series of } \\
2009 \\
\text { "Integration } \\
\text { of EE in } \\
\text { the Tertiary } \\
\text { Educational } \\
\text { Curriculum } \\
\text { in the CWTS } \\
\text { under the } \\
\text { NSTP." } \\
\text { PE }\end{array}$ & - & - \\
\hline $\begin{array}{l}\text { BSEd in } \\
\text { English }\end{array}$ & STS & - & $\begin{array}{l}\text { NSTP } \\
\text { PE }\end{array}$ & - & - \\
\hline $\begin{array}{l}\text { BSEd in } \\
\text { Filipino }\end{array}$ & STS & - & $\begin{array}{l}\text { NSTP } \\
\text { PE }\end{array}$ & - & - \\
\hline $\begin{array}{l}\text { BSEd in } \\
\text { Mathematics }\end{array}$ & STS & - & $\begin{array}{l}\text { NSTP } \\
\text { PE }\end{array}$ & $\begin{array}{l}\text { Appreciate Mathematics as } \\
\text { an opportunity for creative } \\
\text { work, moments of enlighten- } \\
\text { ment, discovery and gaining } \\
\text { insights of the world. }\end{array}$ & - \\
\hline
\end{tabular}


Alma M. CORPUZ, Teody C. SAN ANDRES, Julieta M. LAGASCA. Integration of environmental education (EE) in teacher education programs: Toward sustainable curriculum greening

PROBLEMS

OF EDUCATION

IN THE $21^{\text {st }}$ CENTURY

Vol. 80 , No. 1,2022

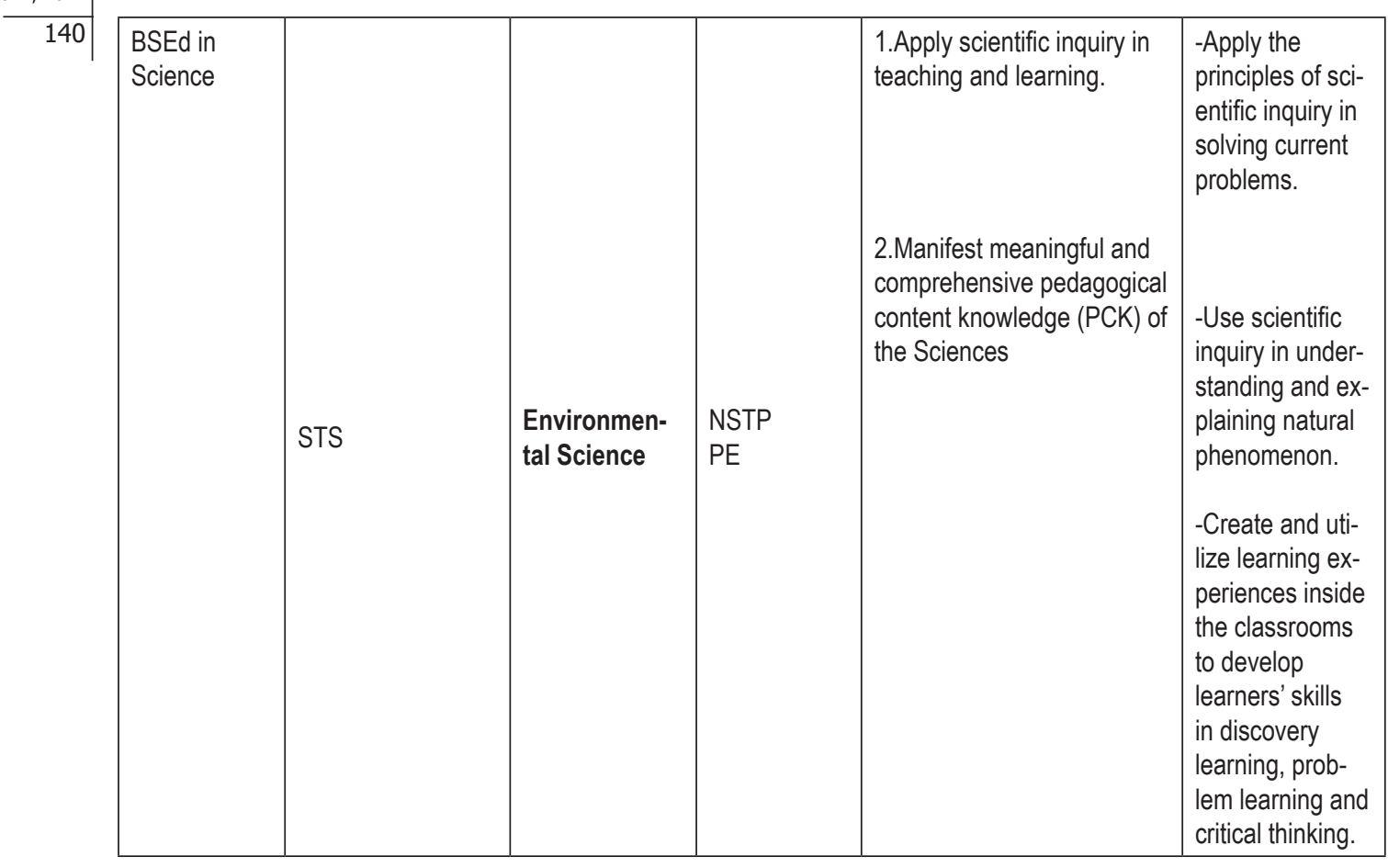


Alma M. CORPUZ, Teody C. SAN ANDRES, Julieta M. LAGASCA. Integration of environmental education (EE) in teacher education programs: Toward sustainable curriculum greening

PROBLEMS

OF EDUCATION

IN THE $21^{\text {st }}$ CENTURY

Vol. 80 , No. 1, 2022

\begin{tabular}{|c|c|c|c|c|c|}
\hline $\begin{array}{l}\text { BSEd in So- } \\
\text { cial Studies }\end{array}$ & . & $\begin{array}{l}\text { Gum } \\
\text { raphy, Physical } \\
\text { Geography } \\
\text { Geography }\end{array}$ & ( & 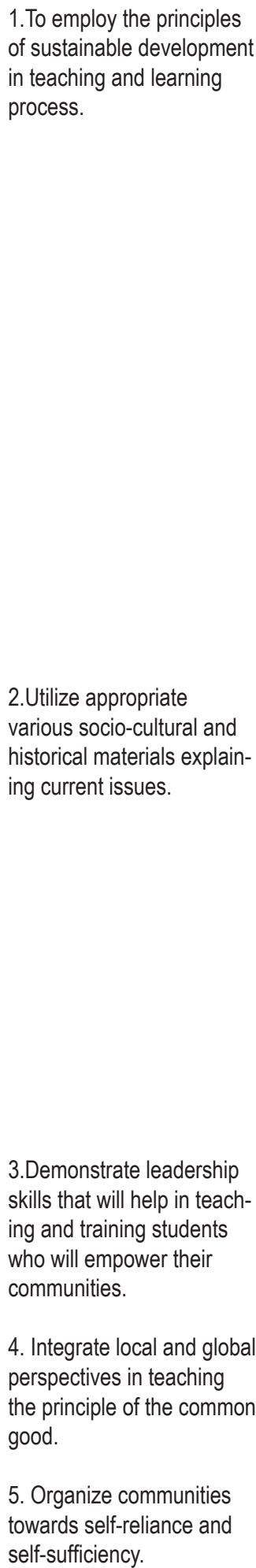 & $\begin{array}{l}\text {-Initiate advoca- } \\
\text { cy campaigns } \\
\text { towards the } \\
\text { attainment of } \\
\text { sustainable } \\
\text { goals. } \\
\text {-Organize } \\
\text { initiatives for } \\
\text { stewardships } \\
\text { of natural } \\
\text { resources. } \\
\text {-Participate } \\
\text { in activities } \\
\text { that promote } \\
\text { environmental } \\
\text { consciousness. } \\
\text {-Integrate the } \\
\text { environmental } \\
\text { principles in } \\
\text { teaching and } \\
\text { learning. } \\
\text {-Relate current } \\
\text { events with } \\
\text { available } \\
\text { historical data } \\
\text { to help students } \\
\text { develop critical } \\
\text { perspectives } \\
\text { towards social } \\
\text { issues. } \\
\text {-Draw connec- } \\
\text { tions between } \\
\text { and among } \\
\text { people, events, } \\
\text { and places to } \\
\text { analyze local } \\
\text { and global social } \\
\text { issues. }\end{array}$ \\
\hline
\end{tabular}


Alma M. CORPUZ, Teody C. SAN ANDRES, Julieta M. LAGASCA. Integration of environmental education (EE) in teacher education programs: Toward sustainable curriculum greening

PROBLEMS

OF EDUCATION IN THE $21^{\text {st }}$ CENTURY Vol. 80, No. 1,2022

\begin{tabular}{|c|c|c|c|c|}
\hline $\begin{array}{l}\text { BSEd in } \\
\text { Values } \\
\text { Education }\end{array}$ & STS & $\begin{array}{l}\text { NSTP } \\
\text { PE }\end{array}$ & $\begin{array}{l}\text { 1. Exhibit critical minded- } \\
\text { ness in analyzing local, re- } \\
\text { gional, national, and global } \\
\text { trends and issues relevant o } \\
\text { values education. } \\
\text { 2. Show passion and } \\
\text { commitment in becoming } \\
\text { advocate of universal } \\
\text { values of openness, peace, } \\
\text { tolerance, social justice, and } \\
\text { respect for human rights. } \\
\text { 3. Demonstrate commitment } \\
\text { to students' development for } \\
\text { personal renewal and social } \\
\text { transformation. } \\
\text { 4.Manifest commitment } \\
\text { to community service to } \\
\text { promote social values } \\
\end{array}$ & $\begin{array}{l}\text {-Engage } \\
\text { learners in an } \\
\text { in-depth discus- } \\
\text { sion of current } \\
\text { societal trends } \\
\text { and issues. } \\
\\
\text {-Designing rel- } \\
\text { evant curricular } \\
\text { and co-curricular } \\
\text { programs pro- } \\
\text { moting universal } \\
\text { values. } \\
\\
\text {-Utilizes different } \\
\text { approaches for } \\
\text { social transfor- } \\
\text { mation } \\
\\
\text {-Plan and man- } \\
\text { age community } \\
\text { development } \\
\text { programs } \\
\text { for values } \\
\text { enhancement of } \\
\text { the people in the } \\
\text { community. } \\
\text {-Initiate and } \\
\text { implement com- } \\
\text { munity service } \\
\text { programs to } \\
\text { promote values } \\
\text { development for } \\
\text { social transfor- } \\
\text { mation. } \\
\text {-Engage in } \\
\text { decision-making } \\
\text { activities con- } \\
\text { cerning moral } \\
\text { and ethical } \\
\text { values. }\end{array}$ \\
\hline $\begin{array}{l}\text { CMO No. } 75 \text {, } \\
\text { s. } 2017\end{array}$ & & & $\begin{array}{l}\text { Graduates of State } \\
\text { Universities and Colleges } \\
\text { (SUCs) must have the } \\
\text { competencies to support } \\
\text { "national, regional, and local } \\
\text { development plans. }\end{array}$ & \\
\hline
\end{tabular}


Alma M. CORPUZ, Teody C. SAN ANDRES, Julieta M. LAGASCA. Integration of environmental education (EE) in teacher education programs: Toward sustainable curriculum greening

Received: November 20, 2021

Accepted: January 28, 2022

PROBLEMS

OF EDUCATION

IN THE $21^{\text {st }}$ CENTURY

Vol. 80 , No. 1, 2022

143

Cite as: Corpuz, A. M., San Andres, T. C., \& Lagasca, J. M. (2022). Integration of environmental education (EE) in teacher education programs: Toward sustainable curriculum greening. Problems of Education in the $21^{\text {st }}$ Century, 80(1), 119-143. https://doi.org/10.33225/pec/22.80.119

Alma M. Corpuz

(Corresponding author)
Doctor in Educational Management (EdD in Educational Management), Master of Arts in Education General Education (MAED in Gen. Ed.),

Faculty Member of College of Science, Tarlac State University, Tarlac City, Philippines.

E-mail: almamarcelinocorpuz@gmail.com

ORCID: https://orcid.org/0000-0002-0477-8317

Teody C. San Andres

PhD, Professor, Bulacan State University, Philippines.

E-mail: teodysanandres.evp@bulsu.edu.ph

ORCID: https://orcid.org/0000-0002-3298-1996

Julieta M. Lagasca
$\mathrm{PhD}$, Professor, Tarlac State University, Tarlac City, Philippines.

E-mail: jd_102885@yahoo.com

ORCID: https://orcid.org/0000-0001-5396-0396 